\title{
Global and Local Agendas: The Milan Urban Food Policy Pact and Innovative Sustainable Food Policies in Euro-Latin American Cities
}

\author{
Diego Martín and Rosa de la Fuente *(D)
}

check for updates

Citation: Martín, D.; de la Fuente, R. Global and Local Agendas: The Milan Urban Food Policy Pact and Innovative Sustainable Food Policies in Euro-Latin American Cities. Land 2022, 11, 202. https://doi.org/ $10.3390 /$ land11020202

Academic Editor: Antonio Sianes

Received: 29 December 2021

Accepted: 27 January 2022

Published: 28 January 2022

Publisher's Note: MDPI stays neutral with regard to jurisdictional claims in published maps and institutional affiliations.

Copyright: (C) 2022 by the authors. Licensee MDPI, Basel, Switzerland. This article is an open access article distributed under the terms and conditions of the Creative Commons Attribution (CC BY) license (https:// creativecommons.org/licenses/by/ $4.0 /)$.
Faculty of Political Sciences and Sociology, Campus de Somosaguas s/n, Complutense University of Madrid, 28223 Madrid, Spain; dimart11@ucm.es

* Correspondence: rdelafuente@ucm.es

\begin{abstract}
This paper analyzes the relationship between the construction of international agendas and new sustainable local policies. Specifically, it analyzes the framework of sustainable food policy building at global and local scales. In this sense, we explore the international agreement called the Milan Urban Food Policy Pact, and its influence on the development of local and global sustainable food-related policies through different innovative methods. To this end, the process of building the international alliance of local governments for the development of sustainable food systems is analyzed first, and secondly, its locations are investigated through the public actions and programs in three cities of the Euro-Latin American region: Madrid, Quito, and Valencia. Two conclusions are clear after our qualitative study: on one hand, local policies are designed and implemented through a double strategy: the substantive construction of the policy and its inclusion in the global agenda. On the other hand, both dimensions are fundamental and reinforce each other, specifically in the case of urban sustainable food policy.
\end{abstract}

Keywords: Milan Urban Food Policy Pact; local and international agendas of local governments; innovative urban food strategies; Madrid; Quito; Valencia

\section{Introduction}

In the context of globalization, rural and urban local governments have been forced to tackle global challenges due to their impact on local daily life [1,2]. In that sense, the capacity of local governments as political actors facing global problems has been gradually recognized from a functional perspective [3]. However, this theoretical recognition has slightly changed their institutional position in the international arena, especially in the United Nations system, where national governments are still those seated at the decisionmaking round table $[4,5]$. The progressive internationalization of local governments has been broadly studied, highlighting the relevance of the international agendas of local governments mostly around three main activities: (a) demanding the recognition of local governments as political actors in the international arena [4-6]; (b) assuming collective political commitments through the building of international networks, associations, and alliances of local governments [7-9]; and (c) designing and implementing new decentralized development cooperation projects among cities, transmitting knowledge and transferring public programs inspired by the 2030 Agenda for Sustainable Development [10-13].

Those strategies and activities have been accomplished following the new multilateral framework of development sponsored by United Nations conferences and programs since 2015. These conferences and programs include the 2030 Agenda, the Conference of Climate Change (Cop21), the Sendai Framework for Disaster Risk Reduction in 2015 and later, and the New Urban Agenda in 2016, among others [14].

Around these international debates, the food issue has been gaining increasing attention as a core problem of human development. The academic and political debate to 
conceptualize the food problem has manifested during international food conferences. During the official World Food Summit in 1996, the consensual concept developed was food security, understood as: "Food security exists when all the people have physical and financial access at any moment to enough safe and nutritious foods in order to satisfy their food needs and their preferences in order to enjoy an active and healthy life" [15]. Later, with a more critical perspective, during the World Food Summit (2001) in La Habana, the concept of food sovereignty was defined to not only include human needs, but also the right of peoples to define their own food strategies (production, distribution, and consumption) to guarantee the right to food as well as supporting sustainable strategies [16]. Lately, during the last World Food Summit (2021), the crucial relationship between food system strategies and the achievement of Sustainable Goal 2 (Zero Hunger) has been underlined.

In accordance with the global dimension of the sustainable goals, Sonnino [17] introduced another approach, "the new geography of food security", which presents a bimodal characteristic "encompassing issues of quantity and quality, under- and over-consumption, in both developed and developing countries alike" [17] (p. 190), where the local dimension of food security, in a world with most people living in cities, has a great impact.

This urban dimension of food security is related to historical conditions or dimensions producing inequalities in the access to and consumption of healthy food [17-19]. Those "conditions" [18] or "dimensions" [17] include, among other things, the increase in population, growing urbanization, the change in food habits, the spread of occidental patterns of consumption, the scarcity and exhaustion of resources, and the climate and social crisis.

Those conditions are expressed in different ways in urban contexts, and each city has different resources and capabilities to react, but increasingly, local authorities are facing the food issue. In the global arena, the international networks of local actors and the support of the UN and other governmental and non-governmental international organizations have been relevant in the politization of the food problem. At the local scale, the policy tool commonly used to tackle this issue has been the development of urban food strategies, using a bottom-up perspective [17-26].

To analyze this new context, Sonnino (2016) studied and compared fifteen urban food strategy documents, written by local governments in Canada, the United States and Great Britain, analyzing their aims, narrative building process, and beliefs concerning the role of cities in solving sustainable food problems [17] (p. 191). Moragues-Faus and Sonnino (2019) also explored the role of the UK's Sustainable Food Cities Network in promoting a food system based on trans-local governance [23].

Furthermore, also using Global North cities but with an analytical perspective more focused on the relationship between urban food strategies and the progress of accomplishing the Sustainable Development Goals, Ilieva [27] compared the sustainable urban food strategies of the ten largest cities in North America, trying to underline the capability of this tool to streamline global, national, and local efforts to implement the 2030 Agenda [27]. On the other hand, some researchers have shown how, in cities from the Global South, where food security has been a major issue since the 1970s, those urban food strategies have been less efficient at tackling the food problem through sustainable actions [28,29].

Thus, although the appearance of urban initiatives trying to change food production and promoting sustainable consumption and healthy eating have been recently studied [17-29], we believe it is relevant to develop new studies using the international relations perspective. In that sense, we consider it important to analyze more deeply the imbrication among local and global initiatives in the construction of a global and coherent answer to food security architecture. The aim is to try to analyze how local governments are using global arenas to reinforce their capabilities to implement food strategies at the local scale, and how the international commitments of local authorities are useful in creating a more sustainable global food system. Therefore, in this paper, firstly, we will study the process of building an international alliance of local governments for the development of sustainable food systems, i.e., the Milan Urban Food Policy Pact. Secondly, we will investigate its locations, and through which public actions and programs have been implemented 
different food strategies. Finally, we will compare the process of developing sustainable food systems in three cities, including two from Europe (Madrid and Valencia in Spain) and one from South America (Quito in Ecuador).

\section{Materials and Methods}

The study of local food strategies and the capacity of local governments to coproduce global sustainable actions in this article was carried out using a qualitative perspective and an empirical explicative approach [30] (p. 12). Our methodology can be divided into three different stages: the compilation of information, case selection, and an intensive synchronic strategy of comparison [30] (p. 68). In that sense, first, we have compiled main narratives (debates, policy papers, statements, etc.), considering the role of local authorities in the international arena as well as the role of urban food strategies and other innovative strategies to localize sustainable development goals. To test those narratives, we had the opportunity to gather in Madrid thirty-one key participants, representatives of local governments, city networks, and universities, in a two-day international workshop entitled "Local alliances to face global challenges", celebrated in September 2018 [9]. Secondly, we have selected three cases from the Ibero-American context, because we considered that this area has had a relevant role during the political building of local governments, networks, and statements regarding sustainable food security. To deeply explore those cases, we interviewed key informants in each city, including politicians and former politicians, civil servants, experts, and non-governmental organizations between 2018 and 2020 (Appendix A).

Because the results of Sonnino [17] (2016) and Moragues-Faus and Sonnino [23] (2019) were very interesting and led to a strong capacity to understand similarities and differences among cities, we considered it relevant to use the main questions they paid attention to, with the aim of producing data (ten semi-structured interviews) and analyzing secondary data.

Finally, with the objective of reviewing differences and similarities in local food security strategies and their relationship with the 2030 Agenda, we have compared the three cases in consideration of a significant number of variables but during a short period of time. The systematization and comparison of the different political actions and strategies have been carried out using these analytical categories: (a) main motivation to become engaged with urban food strategy; (b) main actors intervening in the design and implementation of the urban sustainable food strategy; (c) main plans and projects in the city regarding food security; (d) impact and changes after signing the Milan Urban Food Policy Pact (MUFPP); (e) detailed characteristics of its intervention in food security and nutrition; and (f) the perception of the impact of the international development agenda in their territories and the capacity of the cities to be part of it. Those categories were built starting from the theoretical studies of Roberta Sonnino [17] and Baker and de Zeeuw [25], from the content of MUFPP, and after using free coding to analyze our data.

The cases selected include: (1) Madrid, because it is the Spanish capital city with a strong leading role among Ibero-American cities, mainly through the city network of the Union of Ibero-American Capital Cities (UCCI); (2) Valencia, also in Spain, because it has the particularity of having a great historical area comprising a vegetable peri-urban garden called La Huerta (The Orchard), and it has been awarded internationally for its good practices and has received recognition for its sustainable food policy; and (3) Quito, in Ecuador, because it has also been recognized by the Food and Agriculture Organization due to its historical concern for the dimensions of food security. In all these cases, each city launched food strategies in 2018, after signing the Milan Urban Food Policy Pact.

\section{Results}

The main results of our research will be shown in this section. Firstly, we will explain how the Milan Urban Food Policy Pact (MUFPP) was developed and, secondly, we will provide a precise description of each case analysis, using similar categories in order to understand the similarities and differences between the motivations of each city to define their own urban food strategies. 


\subsection{The Milan Urban Food Policy Pact: The Beginning of an Urban Commitment}

During Expo Milan 2015 titled "Feeding the Planet, Energy for Life", the mayor of the Italian city launched an international protocol to tackle food-related problems at the urban level, supported by the Food and Agriculture Organization of the United Nations (FAO). The MUFPP was signed in October 2015 by 123 cities, and at present more than 200 cities have already entered the pact. On their official web page, this protocol is defined as: "an international agreement of mayors. It is more than a declaration; it is a concrete working tool for cities. It is composed by a preamble and a Framework for Action listing 37 recommended actions, clustered in 6 categories. For each recommended action there are specific indicators to monitor progresses in implementing the Pact. The Milan Pact Awards offer concrete examples of the food policies that cities are implementing in each of the 6 Pact categories" [31].

The categories defined are governance, sustainable diets and nutrition, social and economic equity, food production, food supply and distribution, and food waste. Because the main challenge was to prioritize building urban sustainable food systems, governance is a very relevant category; consequently, every city has to create the way of "ensuring an enabling environment for effective action in cities, such as: to facilitate collaboration across city agencies and departments; to strengthen urban stakeholder participation; to identify, map, and support local and grassroots initiatives; to develop or revise urban food policies and plans; and to develop a disaster risk reduction strategy" [31].

The pact has two types of actions: internal and external [32]. The internal and external functions are interlinked, because MUFPP is becoming a space for cooperation and political influence. Firstly, this is because it is a site for food-related policy exchange between those signatories' cities. Secondly, it is a network to interact collectively or individually with other global organizations such as the FAO, and other international foundations such as Local Governments for Sustainability (ICLEI) and Global Partnership on Sustainable Urban Agriculture and Food Systems (RUAF). Thirdly, it has inspired and received recognition by other institutions, especially in the European context.

Specifically, in the European region, the European Commission launched Food 2030 in 2016, a research and innovation policy to transform food systems and ensure everyone has enough affordable, nutritious food to lead a healthy life. Later in 2017, the Food 2030 Expert Group proposed and defined cities "as a new type of food-system partner, which can act as a multi-objective and multi-actor facilitator. In this respect, the 2015 Milan Urban Food Policy Pact was identified as a pioneer municipal project, which has since been strongly supported and followed up by different Food 2030 actions" [33]. In the same way, in 2017, the European Committee of the Regions, in its document entitled "Towards a sustainable EU food policy that creates jobs and growth in Europe's Regions and Cities", underlines the need to support the shift to more sustainable patterns through governance structures such as local food councils and local development partnerships as well as through new bottom-up initiatives such as the Milan Urban Food Policy Pact (MUFPP) [34,35]. In 2020, this institution also recognized the role of local and regional authorities in making food systems more sustainable [35]. Moreover, the European food strategy, known as Farm to Fork (F2F), which was launched in 2020, sets the basis for the transformation of food chains across the EU according to sustainability criteria, assuming that the transition to sustainable food systems "requires a collective approach involving public authorities at all levels of governance (including cities and rural and coastal communities), private-sector actors across the food value chain, non-governmental organizations, social partners, academics, and citizens" [36].

Three elements related to the government scales and political arenas are very significant in the Milan Agreement: (1) it is an initiative fostered by local leadership, which later obtained strong support from the FAO as well as other international recognition; (2) this agreement is the result of a bottom-up collective decision to face the systemic food-related problem shaped at the global scale; and (3) it has become a structuring and dynamizing 
axis for cities that could not have previously been involved in food policies. However, it is necessary to explore city cases to better show the capacity of the Pact.

\subsection{Comparative Analysis of Sustainable Urban Food Strategies: Madrid, Quito and Valencia}

In this section, we will show our analysis of each case using the categories described in Section 2, Materials and Methods, to show the differences and similarities in their approaches, the local coherence of local actions, and the international framework and the interrelation of local and global policies. Cases are presented in alphabetical order.

\subsubsection{Madrid, Spain}

In May 2015, Now Madrid, a new coalition of left-wing parties, grassroot movements, and civic organizations, won the municipal election. Moreover, many other Spanish cities experienced the arrival of "non-institutional" mayors supported by coalitions of environmental social movements and health and housing activists who had been politicized under the context of the economic and austerity crisis. Big cities such as Madrid, Barcelona, Zaragoza, and Valencia, among others, were labelled as the "cities of change". Following our analytical categories, we will now show the case of Madrid's building process of an urban food strategy in this context:

- Main motivations to sign the Milan Food Pact. According to the governmental informant, there were two main motivations: to guarantee the human right to food and to contribute to environmental sustainability (MI1, MI2). These two motivations were intrinsically linked with the main priorities for the city: to create a more sustainable environment through reducing pollution and promoting human rights. However, according to an ecological leader who was interviewed, "Madrid signed the Milan Urban Food Pact because there was a strong ecological movement which pushed the local authorities. Agroecological ideas had been present among social movements in Madrid since the 90s, and finally in 2014, the Platform for Agroecology was created" (MI3). In fact, in 2014, social economy activists as well as agroecology organizations had signed the "Letter for Food Sovereignty in our Municipalities". In this public proposal, among other actions, the creation of agroecological councils in each city, the sustainable protection of agrarian soils, and support for agricultural employment and sustainable local economic development were claimed.

- Main actors involved in the design and implementation of the urban food policy. During the design and implementation of the food policy, the relevant actors were the local government, the Platform for Agroecology, the Association of Neighborhood Associations, and the FAO's Spanish Office. Inside the local government, many councils were involved (equity, social rights and employment, health, security and emergencies, and environmental issues and mobility, coordinated by the Council of Territorial Coordination) (MI2, MI2).

- Impact and changes generated after signing MUFPP. After signing the Pact, sustainable and healthy food issues were moved to the center of the political agenda. Until then, there were several actions that were dispersed and not strategically planned (MI1, MI2). In order to follow up on the commitments, a monitoring table was established with the usual participation of all the actors involved.

- Main programs and city projects. The main city hall program around food issues was the Urban Food Strategy (2018-2020), whose design began after engagement with the MUFP, and was finally presented in July 2018. The strategy tried to coordinate previous actions and outline new proposals. Some of those previous actions had been developed by the innovative action of social activists and associations, such as community green gardens and school green gardens, which were later supported by the town hall (MI3, MI4). New innovative mechanisms were introduced to change food dynamics; for example, innovative public procurement was used to include ecological and local food at nursery schools, and social economy was introduced in the local food distribution in two peripherical neighborhoods thanks to the financial 
support of the MARES project selected as an Urban Innovative Action by the European Commission (MI4) [37-39].

There are two specific contributions to food security and nutrition in Madrid's strategy: one is its integrality and the other, the effort to guarantee the human right to food (MI1, MI2, MI4). Thanks to the multi-stakeholder and multisector composition of the monitoring table as well as the approval of the food strategy, the transversality of the policy was the key element of the policy. This systemic approach is one of the essential aspects underlined by Sonnino [17] (p. 197) regarding urban food strategies.

Another concern is the perception regarding the impact of the international agenda at a local scale, and the city's capacity to influence it. About this point, there was a positive perception concerning the role of local authorities developing food strategies and also regarding localizing the sustainable development goals (MI2, MI4). In that sense, they considered that international organizations were paying attention to the cities, because they have been the political actors more involved in localizing the 2030 Agenda, not only through individual policies, but also by working in networks and through political alliances.

\subsubsection{Quito, Ecuador}

Quito is one of the more relevant cities in the Latin-American region in relation to the urban and peri-urban food policies developed, as the FAO underlined in 2014 [40]. Moreover, because the UN Habitat Summit was held in Quito in 2016, many politicians, advisors, and city councilors were able to be involved in the debates regarding sustainable urban policies. Although the city joined the MUFP in January 2016, there was no urban food strategy at that time, just as there was none in Madrid or Valencia. However, since the 2000 s, there has been several initiatives related to food production (QI3), such as a wellestablished urban agriculture policy and some small actions supporting small producers. The urban food strategy was presented in 2018.

- Main motivations to sign the Milan Food Policy Pact. In Quito, the main motivation to begin being involved in food-related policies was historically to "regulate the spontaneous urban agriculture production and secondly to promote the surplus commercialization" (QI1). According to the FAO [31], the historical proliferation of urban gardens in Quito can be explained as a spontaneous strategy to access food by the previous waves of internal migration since the 1980s. Since the beginning, those orchards were tolerated by urban planners, and an Urban Participatory Agriculture Program (AGRUPAR) was developed in 2000. In this case, the economical approach of the food policy is more relevant, because AGRUPAR has ben guided by the Metropolitan Agency for Economic Promotion (CONQUITO) since 2005. Therefore, this agency also supervised the urban food strategy.

- Main actors involved in the design and implementation of the urban food policy. Among the actors involved in the elaboration of the urban food strategy in this city, were the universities, the Agriculture Chamber of Zone 1, general consumers, food processing associations, agroecological producers and consumers, the touristic sector, the national government with representation of the Ministry of Agriculture and the Ministry of Health, and the Pichincha provincial-regional government. The coordination of the process was held by CONQUITO, where there were also two councilors from the Social Responsibility and Shared Value Area, which has the ability to localize the 2030 Agenda. (QI1, QI2).

- Main programs and city projects. The oldest food-related action implemented in Quito was the Urban Participatory Agriculture Program (AGRUPAR), launched in 2000 thanks to the support of the United Nations and other international organizations, located in the El Panecillo neighborhood, in the historical city center (QI1, QI2, QI3). After a long trajectory of AGRUPAR, between 2015 and 2017, Quito was part of an alliance of seven cities called "the City Region Food System Partner Cities", which was supported by the FAO and the RUAF foundation. This partnership provided the 
city with a comprehensive diagnosis of its food system, which was the first step of the urban food strategy, which was finally launched in October 2018.

- Impact and changes generated after signing the MUFP. The international partnership and the MUFPP membership (2016) allowed the local authorities to increase the visibility of the food issue in the city. After this, the food question was progressively included in different strategies and programs, until the Agri-Food Strategy was presented in 2018. In this case, the rural and peri-urban relation with the city regarding the food system was clearly a focus of the strategy.

- Specific contribution to food security and nutrition. The main objective of the urban food strategy in Quito is to guarantee food security. This food security is focused not only on food access but also on the quality of food production and the way in which food is consumed. Therefore, sustainable and responsible consumption is relevant, as much as the aim to increase the capacity of production following agroecological, fair trade, and solidarity market practices.

- Perception regarding the impact of the international agenda at the local scale, and the city's capacity to influence it. In this sense, for the experts in Quito, ever since the MUFPP has been followed by the FAO, it is easier to work locally and internationally with the same agenda. Moreover, food-related problems and food policies have become key elements for local authorities' networks, such as C40, ICLEI, and UCCI (QI1). This confluence of objectives and approaches among local and global arenas is the best way to implement food strategies, because all efforts are joined (QI3).

\subsubsection{Valencia, Spain}

The economic crisis of 2008 had a deep impact in the city, even more than the Spanish average, because the real estate sector had a lot of weight in the local economy [32]. Moreover, the agriculture sector had been engulfed in a deep crisis, due to the decline of aging farmers, the fall in the prices of agricultural products, and the loss of more than $45 \%$ of agricultural soils since 2009 due to urban pressure [37]. Therefore, as much as in Madrid, the influence of the "Letter for the Sovereignty of our Municipalities" was important. Moreover, in Valencia, a historical social movement in defense of the territory and "La Huerta" (peripheral orchard area) exists. In that sense, many of the food-related projects were born thanks to the social innovation in the face of public inaction (VI1), such as the green communitarian gardens in abandoned urban plots, and the renaturation and cleaning of natural areas and wetlands [37-39].

In 2015, for the first time, a local and regional party called "Commitment" won the local elections, and a new mayor was elected with the support of left-wing parties, with the conservative party as the opposition. It was the greatest ideological change since 1991, when the conservative party had started ruling the city. It is important to add that the new mayor was very concerned with agriculture and food production, because he had studied agricultural engineering and taken several courses on food technology.

- Main motivations to sign the Milan Food Pact. In this case, there were economic and social motivations to sign the Milan Food Pact. The priority of the town hall was to defend and praise the farmer's role, guaranteeing the economic viability of farms' production activity. The city of Valencia is situated in the middle of the region called La Huerta (The Orchard) and, therefore, it was a priority to recover the food production and distribution of this area, as well as the heritage of the territory, in order to avoid the loss of knowledge.

- Main actors involved in the design and implementation of the urban food policy. With the arrival of the new local authority, a new Council of Agriculture for The Orchard and the town of Valencia was created in 2015. Other relevant actors involved in this municipal action were several non-governmental associations, such as the local section of Food Justice, and NGOs such as Mundubat, as well as academics from the Centre for Rural Studies and International Agriculture (CERAI) and the Chair of Sustainable Earth at the Polytechnic University of Valencia, among others. 
- Main programs and city projects. In 2015, after signing the MUFPP, the Integral Action Plan for the Promotion of Municipal Agricultural Activities and Municipal AgriLand was launched. From the beginning, this plan was focused on supporting social and academic innovation practices that already existed (VI1, VI2). Later, in 2018, an advisory and participative body, the Municipal Food Council, was created to coordinate food policies, with a wide open and participatory structure trying to integrate actors, actions, and sectors. This was where the Valencia 2025 Agri-Food Strategy was designed, trying to establish a sustainable agri-food system in which relationships between the community and territories (urban, rural, and peri-urban) were balanced, and based on social and environmental justice [41,42].

- Impact and changes generated after signing MUFP. Although there was an already existing social and agroecological movement in the city, the Pact has had a clear influence as a starting point for creating the Municipal Food Council and, consequently, the food strategy (VI1, VI2, VI3). This process has generated a new governance structure in the city, based on mutual recognition and shared commitment around food-related policies.

- Specific contribution to food security and nutrition. According to our research and interviews, the most relevant contribution of the urban food strategy and food-related policies is to defend the uniqueness of its territory and the small-scale farmers. Analyzing the institutional policies and the social innovation practices, the reterritorialization of the food system, using Sonnino's concepts, was a key element of this strategy. Moreover, the creation of the first Municipal Food Council, as a participatory governmental structure, was very significant in diagnosing different problems affecting the local population, such as obesity, being overweight, and malnutrition, for example [42,43].

- Perception regarding the impact of the international agenda at the local scale, and the city's capacity to influence it. In 2017, 85 city delegations and more than 300 people met in Valencia for the 3rd Annual Gathering of the Milan Pact, and it was declared as the World Sustainable Food Capital. This was an international recognition of the city due to its development of food polices. Progressively, politicians and citizens are receiving more support from international and supranational organizations, such as the FAO and the European Commission. This means more funding and financial support for strategic projects to develop a systemic change (VI1, VI2, VI3). In that sense, Valencia was selected to be the headquarters of the World Center of Sustainable Food (CEMAS), which was promoted by the city hall in alliance with the FAO and opened in 2019. These kinds of alliances among local authorities and UN organizations to spread the need to develop sustainable urban food policies are very relevant to understanding the functioning of mutual (i.e., local and global) relationships.

\section{Discussion}

In this section, we will discuss our results and how they can be interpreted from the perspective of the studies of Sonnino [17], Moragues and Sonnino [23], Ilieva [27], Grasa and Sánchez [32], Salom, Pitarch, and Sales-Ten [38], Medina García, de la Fuente, and Van der Broeck [38] and of our working hypotheses, which state that, on the one hand, local policies are designed and implemented through a double strategy, the substantive construction of the policy, and its inclusion in the global agenda. On the other hand, both dimensions are fundamental and reinforce each other specifically in the case of urban sustainable food policy. We will present the results in an enunciative manner and then develop them in more detail.

First of all, it demonstrates the emergence of an urban dimension of food insecurity and the need for a public response to address this situation, with innovative elements that Sonnino claims as surpassing the traditional macro and micro approaches to the food issue [17]. These public responses, which are the urban food strategies tested in the three case studies, exist not only in the major North American [27] and English [17,23] cities, but also in continental Europe and South America. 
Secondly, it is also shown that urban food strategies are a useful tool to increase the level of localization of SDGs [27] in principle in large and intermediate cities.

Thirdly, it is shown that in the cases studied, the process of social innovation precedes and accompanies urban food strategies [37-39].

The development of the internal and external functions [32] of the network of cities of the Milan Pact is also demonstrated, as explained below.

One of our main objectives was to show the mutual relationship between local and global political arenas. One of the directions of this relationship has been clearly shown, especially after analyzing how food strategies have been spread among the three cities, and how the three cities have pursued a similar objective but used different approaches, after signing a common commitment. Meanwhile, international organizations and a supranational political structure have supported and followed the road started by local governments. The other direction with regards to cities' capacity to influence the international agenda, it can be said that Valencia and Quito have managed to position themselves as international references regarding urban food policies. However, as mentioned in the introduction and in Section 3.1, the capacity of cities to influence the international system should not necessarily be measured in individual terms, but through instruments of action such as networks of cities, such as the MUFPP. In this sense, the influence of cities, through the MUFPP, in the capacity to place the issue of sustainability of urban food systems is demonstrated, so that the FAO itself joined the Pact in 2015 and, in 2021, the General Secretary of the United Nations convened the United Nations Food Systems Summit, with criticism from academics and organizations [43].

In that sense, the role of the international development agenda to inspire and legitimate local actions and vice versa is also demonstrated [27]. Local food strategies are one aspect of localizing sustainable development goals, but not the only one, because they clearly influence the global and regional arena. However, the cocreation of food policies and the exchange of knowledge and experiences are also possible, not only because of the international alliances among local authorities, but also due to the capacity of international governmental organizations, such as the FAO, along with other non-governmental and private international foundations, to support them.

What the three cases analyzed demonstrate is a local dimension of food insecurity that demands a public response from local governments [17]. We have found similarities and differences between local innovative practices to accomplish the objectives and goals of the development agenda, particularly in relation to food-related issues. Long perspective analysis and the contextualization of each city has let us understand the relevance of the location of each city and the way they started to implement actions and programs to solve problems related to food security, although they shared the same international commitments. In that sense, the geography of food security, using Sonnino's concept, is asymmetrical and heterogeneous. Food access, the quality and quantity of food, and unbalanced consumption are dissimilar, both between each city, and within them. In the same way, political contexts and social backgrounds are different, as are the ways in which the food problems are politized.

In that sense, the comparison allows us to see how each city had their own motivation to sign the MUFPP. In fact, economic reasons are behind two cases: Valencia and Quito. Those cities are characterized by being territories in which urban and peri-urban areas live together, and where small farmers used to produce food, although without enough success or with progressive decline. However, in Madrid, although the local production and consumption of products in proximity to the city is important, the human rights and environmental issues are more relevant to engage MUFPP.

One important finding regarding urban responses to food problems has been the social origin of most of the actions before the MUFPP commitment. According to the recent literature concerning innovation, we can consider that social innovation is when social actors, neighbors, urban activists, grassroots associations, etc., organize themselves to find 
creative solutions to the provision of individual and collective needs that have been not taken into account by the public institutions, and not even the market [37-39].

In that sense, in the three cases, local communities of neighbors in alliance with ecologists, peasants, or farmers had started to implement innovative solutions. Urban gardens were created in Quito after the arrival of migrant waves and the need to access food. In Valencia, although the great and historical orchard was declining, empty plots were used to create urban gardens as a mechanism of cohesive practices in the neighborhood, as well as in Madrid. In Madrid, the urban gardens were spaces symbolically gained for the real estate, and school urban gardens were used to raise awareness about the need for eating healthy food and to introduce ecological perspectives. Later, authorities recognized those efforts, converted them into policies, and replicated them. Moreover, clearly in the case of Madrid and Valencia, ecological and social movements put pressure on the local authorities to engage food strategies and policies that were more sustainable, because of the political alliance known as "cities for change".

Although it is important to underline how these social innovation practices started, it is also relevant to notice how local authorities, in the context of MUFPP, were able to introduce governance as a tool to implement the change in the global and local food systems. Those mechanisms of participation have been an essential part of the strategies' and policies' design, channeling demands and opening the possibility of follow-up actions, programs, and goals. This has been recognized by the European Commission, which introduced a similar approach to their own strategy.

In the case of Quito, the support of the FAO since the 2000s was essential to introduce food policies and strategies, as well as in the case of the city of Milan and Valencia. However, later, those cities themselves were able to become international sites from which new policies and experiences spread. In that sense, the proliferation of local authorities' alliances and networks show how international instruments are relevant to reinforce each other and each other's domestic policies, as much as to act as politically united in the global arena.

\section{Conclusions}

Following Sonnino, it can be said by way of synthesis that " [ . . ] the concept of food security today evokes a series of interrelated public health, political, socioeconomic and ecological crises that threaten human survival and, for this reason, require strong public intervention" [17] (p. 191).

This series of interrelated crises takes on a more urgent dimension from an urban perspective, if it is noted that high poverty rates linked to growing situations of food insecurity occur mainly in cities [26]. In Latin America and the Caribbean, for example, it is estimated that there are 53.4 million people living in conditions of extreme urban poverty [26] (p. 8). Taking into account the OECD-FAO projections [44] that anticipate, in the medium term, an increase in food prices to values similar to those that existed before 2008, and the fact that the urban poor spend most of their income on food, we are facing a rather complex scenario, characterized by environmental unsustainability, health emergency, and food insecurity, which only deepens the multiple social inequalities existing at the global level.

Faced with such a scenario, a public response that could address this challenge from an integral point of view is imperative, overcoming the sectoral approaches that have predominated until now, and at the same time replacing the preeminence of mercantile and financial logic, under which food is directed to where it is best paid for, rather than where it is most needed [45].

In this context, we believe it is necessary to recover those experiences that have been implemented by numerous local governments, providing a comprehensive and innovative response to this challenge, which could be replicated at other scales. As mentioned in the introduction, more and more cities are developing urban food strategies to address the challenge of building more sustainable food systems and, at the same time, they are working together by taking collective steps towards changing the global food system. 
It is within this international agenda that local governments propose reconfigurations regarding roles and responsibilities, because many innovative experiences have emerged from this scale of government, having originated transformations in food production and consumption patterns.

These responses offer an alternative to global food production and consumption chains, in which the territorial component of the food system is proposed to be increased over the globalized one. It is argued here that a deepening and dissemination of these strategies on a larger scale could represent an alternative path that could avoid, in the future, a scenario such as the present one. However, it is important not to be confused: it is not being said that cities will feed everyone in the world in a sustainable way. This would not be possible, nor even desirable. What is being suggested is the need to study these integral models of approaching the food issue that holistically contemplate all the phases and actors of food systems, as a contribution for scaling up and, thus, working on the development of sustainable food systems in another dimension. How can we scale up this model? This is the challenge of international action and collective advocacy that local governments seem to be able to take up.

Future research should be conducted to analyze the relationship between those food strategies, which are locally and internationally supported, and the innovative answers to food access during the COVID-19 pandemic. In that sense, AGRUPAR and a new project called Healthy Markets have kept working to safeguard food access and the productive fabric in Quito, as well as in other Latin American cities such as San Salvador and Rio de Janeiro.

Finally, we also believe it is necessary to study the limitations of these strategies, due to issues such as the scale of the policies, budgets, or the alternation of governments of different political leanings in the cities, and what the response of the city networks is in these cases.

Author Contributions: Conceptualization, D.M. and R.d.l.F.; methodology, D.M. and R.d.l.F.; analysis, D.M. and R.d.l.F.; investigation, D.M. and R.d.l.F.; resources, D.M.; data curation, D.M.; writingoriginal draft preparation, D.M.; writing — review and editing, R.d.l.F.; supervision, R.d.l.F.; funding acquisition, R.d.l.F. All authors have read and agreed to the published version of the manuscript.

Funding: This research was funded by the Ministry of Economy, Innovation, and Competitiveness, grant number "CITiTALENT", CSO2016-74888-C4-4-R (AEI/FEDER, UE) and by the Ministry of Science and Innovation, grant number "IMAD COVID" I+D+i/PID2020-112734RB-C33, funded by MCIN/AEI/10.13039/501100011033/.

Institutional Review Board Statement: Not applicable.

Informed Consent Statement: Not applicable.

Acknowledgments: The authors sincerely thank the invaluable support of the doctoral group (Lab IPPU-UCM) LAB IPPU (google.com (accessed on 25 January 2022)). Weekly inspiration and kindness are also sources of knowledge. We are also very grateful for the accurate comments and suggestions of the reviewers who helped us to improve our first manuscript's version.

Conflicts of Interest: The authors declare no conflict of interest. The funders had no role in the design of the study; in the collection, analyses, or interpretation of data; in the writing of the manuscript; or in the decision to publish the results.

\section{Appendix A}

Several interviews, informal conversations, and participatory observations were held in the cities (2016-2020). In September 2018, the authors gathered a meeting with thirtyone local authorities, techno-political advisors, and experts in local agendas from Spain and Latin American cities. This event was coordinated by UCCI and UCM University thanks to the financial support of EULAC. The reporting of the event as well as the result of a questionnaire have been used in the first stage of the research. Moreover, ten semi-structured interviews were held, of which seven were recorded and transcribed in 
Spanish and are quoted in the article. The interviews include: MI1 (informant in Madrid, techno-political advisor), MI2 (informant in Madrid, Council of Territorial Coordinator), MI3 (informant in Madrid, agroecological activist), MI4 (informant in Madrid, expert), MI5 (informant in Madrid, MARES project coordinator), QI1 (informant in Quito, technopolitical advisor), QI2 (informant in Quito, NGO expert), QI3 (informant in Quito, former mayor), VI1 (informant in Valencia, expert), VI2 (informant in Valencia, techno-political advisor), and VI3 (informant in Valencia, agroecological activist). The main questions were: What are the main motivations for cities in general and your city in particular to start developing urban food strategies and related policies? How long has your city been developing food security policies? Are these motivations related to the signing of the Pact of Milan, and which one is it? What are the main programs and projects that are being developed in relation to food policies in your city? In relation to the participation of citizens and civil society organizations, how is this policy being built? What is the specific contribution that cities make to the field of food security? All those interviews were carried out and transcribed in Spanish.

\section{References}

1. Sassen, S. Local actor in global politics. In Denationalization: Territory, Authority and Rights in a Global Digital Age; Princeton University Press: Princeton, NJ, USA, 2004.

2. Curtis, S. Cities and Global Governance: State Failure or a New Global Order? Millenium J. Stud. 2016, 44, 455-477. [CrossRef]

3. García Segura, C. La evolución del concepto de actor internacional en la teoría de las relaciones internacionales. Pap. Rev. Sociol. 1993, 41, 13-31.

4. Russell, R. El Estado Nación y los actores gubernamentales no centrales: Una relación complementaria. In La Política Internacional Subnacional en América Latina, 1st ed.; Maira, L., Ed.; Libros del Zorzal: Buenos Aires, Argentina, 2010; pp. 83-106.

5. Fernández de Losada, A.; Romero, M. Los Gobiernos Locales en la Agenda Internacional: ¿Actores o Espectadores? Cuadernos Para la Internacionalización de las Ciudades, $n^{\circ}$ 7, 1st ed.; Gobierno de la Ciudad de México: Mexico City, Mexico; Intendencia de Montevideo: Montevideo, Uruguay, 2016; ISBN 9786070250934.

6. $\quad$ Oosterlynck, S.; Beeckmans, L.; Bassens, D.; Derudder, B.; Segaert, B.; Braeckmans, L. The City as a Global Political Actor, 1st ed.; Routledge: New York, NY, USA, 2019.

7. Sánchez Cano, J. Los Gobiernos no Centrales y sus Redes: Análisis de su rol Como Actores en la Gobernanza Global. Ph.D. Thesis, Universidad Complutense de Madrid, Madrid, Spain, 2015.

8. Fernández de Losada, A.; Abdullah, H. Repensando el Ecosistema de Redes Internacionales de Ciudades: Retos y Oportunidades; CIDOB: Barcelona, Spain, 2019.

9. de la Fuente, R.; Martín, J.; Agüero, B.; García, A.; Rodríguez, M.; Martín, D. Alianzas Locales Para los Retos Globales. Coleccion de Cuadernos Para la Internacionalización de las Ciudades, $n^{\circ}$ 9, CDMX, 1st ed.; UCCI, Universidad Complutense de Madrid: Madrid, Spain, 2019; ISBN 97860702 5093. Available online: https://www.acimedellin.org/wp-content/uploads/2019/10/cuadernoallas-09.pdf (accessed on 28 December 2021).

10. UN: The Future We Want the United Nations We Need, Update on the Work of the Office on the Commemoration of the UN's 75th Anniversary. 2020. Available online: https:/ /www.un.org/en/un75/presskit (accessed on 28 December 2021).

11. GFT: The Role of Local and Regional Governments in the Future Global Governance of the International System, Global Task Force of Local and Regional Governments (GFT), VISIONING REPORT UN75. Available online: https://www.un7 5localandregionalvisionreport.global-taskforce.org/es/ (accessed on 12 December 2021).

12. de la Fuente, R. La importancia de los actores locales y regionales en los procesos de desarrollo en el contexto de la globalización. In Los Nuevos Actores en la Cooperación Internacional. El Papel de los Gobiernos Locales y Regionales, 1st ed.; Instituto Universitario de Desarrollo y Cooperación, Los Libros de la Catarata: Madrid, Spain, 2010; pp. 15-34.

13. United Cities and Local Governments. Our Post-2015 Journey. 2015. Available online: https://www.uclg.org/en/resources/ publications (accessed on 28 December 2021).

14. World Food Summit. Rome Declaration on World Food Security and Plan of Action of the World Food Summit, Rome. 1996. Available online: https:/ /www.fao.org/3/w3613e/w3613e00.htm (accessed on 28 December 2021).

15. Vía Campesina. Declaración Final del Foro Mundial Sobre Soberanía Alimentaria. La Habana. 2001. Available online: http: / / www.movimientos.org/cloc/show_text.php3?key=1178 (accessed on 28 December 2021).

16. Sonnino, R. The new geography of food security: Exploring the potential of urban food strategies. Geogr. J. 2016, 182, 190-200. [CrossRef]

17. Wiskerke, J. Urban Food Systems. In Cities and Agriculture-Developing Resilient Urban Food Systems; RUAF Foundation: Amsterdam, The Netherlands, 2015; pp. 1-25.

18. Karanja, N.; Njenga, M. Alimentar las ciudades. In VVAA, La situación del Mundo; Fuhem Ecosocial/Icaria: Madrid, Spain; Barcelona, Spain, 2011. 
19. Yacamán, C. El Paradigma del Proyecto Agrourbano: La Agricultura Defendida Desde la Ciudad. Urbano. 2017. Available online: http: / / www.redalyc.org/articulo.oa?id=19853617002 (accessed on 4 May 2018).

20. Moragues, A. Cambiar la política alimentaria empezando desde abajo. In Revista Soberanía Alimentaria, Biodiversidad y Culturas; c/Girona 25, principal; GRAIN: Barcelona, Spain, 2014; pp. 16-20; ISSN 2013-7567.

21. Dubbeling, M. CITYFOOD: Linking Cities on Urban Agriculture and Urban Food Systems. ICLEI-RUAF Foundation. 2013. Available online: http:/ / www.iclei.org/index.php?id=1348 (accessed on 4 May 2018).

22. Moragues-Faus, A.; Sonnino, R. Re-assembling sustainable food cities: An exploration of translocal governance and its multiple agencies. Urban Stud. 2019, 56, 778-794. [CrossRef]

23. Pothukuchi, K.; Kaufman, J.L. Placing the food system on the urban agenda: The role of municipal institutions in food systems planning. In Agriculture and Human Values n¹6; Kluwer Academic Publishers: Amsterdam, The Netherlands, 1999; pp. $213-224$.

24. Baker, L.; de Zeew, H. Urban food policies and programmes: An overview. In Cities and Agriculture-Developing Resilient Urban Food Systems; RUAF Foundation: Amsterdam, The Netherlands, 2015; pp. 26-55.

25. CEPAL-FAO. Cómo Evitar que la Crisis del COVID-19 se Transforme en una Crisis Alimentaria. 2020. Available online: https:// www.cepal.org/es / publicaciones/45702-como-evitar-que-la-crisis-covid-19-se-transforme-crisis-alimentaria-acciones (accessed on 25 January 2022).

26. Ilieva, R.T. Urban Food Systems Strategies: A Promising Tool for Implementing the SDGs in Practice. Sustainability 2017, 9, 1707. [CrossRef]

27. Lundqvist, A. Urban Food Systems Strategies in Latin America-A Tool for Local Implementation of the Sustainable Development Goals? Master's Thesis, Lund University, Lund, Sweden, 2019.

28. Warren, S. Urban governance and urban food systems in Africa: Examining the linkages. Cities 2016, 58, 80-86. [CrossRef]

29. Anduiza, E.; Crespo, I.; Méndez, M. Metodología de la Ciencia Política. In Colección Cuadernos Metodológicos $n^{\circ}$ 28, 1st ed.; Centro de Investigaciones Sociológicas: Madrid, Spain, 2009.

30. Milan Urban Food Policy Pact. 2015. Available online: https://www.milanurbanfoodpolicypact.org (accessed on 28 December 2021).

31. Grasa, R.; Sánchez Cano, J. Global and Networking Action of Local Governments: The Case of Development Aid; CIDOB d'Afers Internacionals: Barcelona, Spain, 2013; pp. 83-105. Available online: https://www.jstor.org/stable/23611649 (accessed on 28 December 2021).

32. European Cities Leading in Urban Food Systems Transformation: Connecting Milan \& FOOD 2030. Available online: Europeancities-leading-in-urban-food-systems-transformation.pdf (accessed on 28 December 2021).

33. Opinion of the European Committee of the Regions. Towards a Sustainable EU Food Policy that Creates Jobs and Growth in Europe's Regions and Cities. (2017/C 272/04). Available online: https://eur-lex.europa.eu/legal-content/EN/TXT/?uri= CELEX\%3A52016IR3170 (accessed on 28 December 2021).

34. European Union. The Role of Local and Regional Authorities in Making Food Systems More Sustainable. 2020. Available online: https:/ / cor.europa.eu/en/engage/studies/Documents/Sustainable_food_systems.pdf (accessed on 28 December 2021). [CrossRef]

35. European Commission. The Farm the Fork, Farm to Fork Strategy—Food Safety. Available online: https://ec.europa.eu/food/ horizontal-topics/farm-fork-strategy_es (accessed on 28 December 2021).

36. Salom, J.; Pitarch, M.; Sales-Ten, A. Innovación social: Estrategias urbanas en un contexto de cambio. El caso de la ciudad de Valencia. CIRIEC-España. In Revista de Economía Pública, Social y Cooperativa, $n^{\circ}$ 91; Centre International de Recherches et d'Information sur l'Economie Publique, Sociale et Coopérative: Valencia, Spain, 2017; pp. 31-58.

37. Medina García, C.; de la Fuente, R.; Van der Broeck, P. Exploring the Emergence of Innovative Multi-Actor Collaborations toward a Progressive Urban Regime in Madrid (2015-2019). Sustainability 2021, 13, 415. [CrossRef]

38. Yacamán, C.; Sánchez, S.; de la Fuente, R. La innovación social como herramienta para hacer frente a los retos urbanos: Una aproximación al proyecto "MARES-Alimentación" (Madrid). Doc. D'anàlisi Geogràfica 2021, 67, 365-387. [CrossRef]

39. FAO. Urban and Peri-Urban Agriculture in Latin America and the Caribbean. Rome. 2014. Available online: https://www.fao. org/ag/agp/greenercities/en/GGCLAC/downloads.html (accessed on 28 December 2021).

40. Centro de Estudios Rurales y de Agricultura Internacional. La Maleta Pedagógica "Yo Consumo con Consciencia". 2015. Available online: https:/ / cerai.org/publicaciones-de-cerai/ (accessed on 28 December 2021).

41. Ajuntament de València. Estrategia Agroalimentaria Valencia 2025. 2018. Available online: https://valencia.consellagrari.com/ (accessed on 28 December 2021).

42. Moragues, A. Caminando hacia un consejo alimentario en Valencia. Ayuntamiento de Valencia-Ayuntamiento de Barcelona. 2017. Available online: https:/ / consellalimentari.org/wp-content/uploads/2020/10/caminando-hacia-un-consejo-alimentarioen-valencia.pdf (accessed on 28 December 2021).

43. Canfield, M.; Anderson, M.D.; Mc Michael, P. UN Food Systems Summit 2021: Dismantling Democracy and Resetting Corporate Control of Food Systems. Front. Sustain. Food Syst. 2021, 5, 103. [CrossRef] 
44. United Nations Environmental Program. Collaborative Framework for Food Systems Transformation. A Multi-Stakeholder Pathway for Sustainable Food Systems. 2019. Available online: https://www.oneplanetnetwork.org/knowledge-centre/ resources/collaborative-framework-food-systems-transformation-multi-stakeholder (accessed on 28 December 2021).

45. Oteros-Rozas, E.; Ruiz-Almeida, A.; Aguado, M.; González, J.; Rivera-Ferre, M. A Social-Ecological Analysis of the Global Agrifood System. Arizona State University. 2019. Available online: https:/ /www.pnas.org/content/116/52/26465 (accessed on 28 December 2021). 